\title{
KARAKTERISTIK OGANOLEPTIK DAN KIMIA BAKSO IKAN BARAKUDA (Sphyraena jello) DENGAN SUBTITUSI TEPUNG SAGU (Metroxylon sagu)
}

\author{
Oganoleptic and Chemical Characteristics of Baracuda Fish Meatball (Sphyraena jello) with Subtitution of Sago Flour
} (Metroxylon sago)

\author{
La Tanda*, Haslianti, Suwarjoyowirayatno \\ Jurusan Teknologi Hasil Perikanan, Fakultas Perikanan dan Ilmu Kelautan Universitas Halu Oleo, Kendari, \\ Sulawesi Tenggara, Indonesia \\ *Email korespondensi: odetathan@gmail.com (Telp: 082292745484) \\ Diterima: 10 Januari/ Disetujui 7 April 2021
}

Cara sitasi: Tanda L, Haslianti, Suwarjoyowirayatno. 2021. Karakteristik oganoleptik dan kimia bakso ikan barakuda (Sphyraena jello) dengan subtitusi tepung sagu (Metroxylon sagu). Jurnal Fish Protech. 4(1):72-79.

\section{ABSTRACT}

The aim of this study was to determine the effect of sago starch (Metroxylon sago)addingon the organolepticand proksimat value of barracuda fish balls (Sphyraena jello). The design used in this experiment was a compleately randomized design (CRD) with three times replclation. The parameters abserved were sensory teste (appearance smell, taste and texture) and prosimate analysis or chemical teste (water content, ash content, fat content, protein and carbohydrate content). The results of this study indicate that based on the analisis of vanous treatments with research were $P 1=50 \%$ sago flour : $50 \%$ tapioca starch, $P 2=65 \%$ sago flour : $65 \%$ tapioca starch, $P 3=75 \%$ sago flour : $25 \%$ tapioca starch dan P4=85\% sago flour : $15 \%$ tapioca starch. Did not show a significan effecs an the sensory and chemical quality of barracuda (Sphyraena jello) fish Meat balls but had different mean in each treatment that shows the best quality of fish meat ball treatment $P 3=75 \%$ sago flour : $25 \%$ tapioca flour with on appearance value of 4,05, odor 4,26, taste 4.01 and texture 4,00

Keywords: Barakuda fish, meat ball, sagoo

\section{ABSTRAK}

Tujuan penelitian ini adalah untuk mengetahui pengaruh penambahan tepung sagu (Metroxilon sagu) terhadap nilai organoleptik dan nilai proksimat bakso ikan barakuda (Sphyraena jello). Penelitian in imenggunakan rancangan acak lengkap (RAL) dengan empat perlakuan dan pengulangan sebanyak tiga kali. Parameter yang diamati yaitu uji sensori (kenampakan, bau, rasa dan tekstur) dan analisis proksimat (kadar air, kadar abu, kadar lemak, kadar protein dan karbohidrat). Hasil dari penelitian ini menunjukkan bahwa berdasarkan analisis sidik ragam perlakuan dengan penelitian (P1= tepung sagu 50\%: tepung tapioka 50\%), (P2= tepung sagu $65 \%$ : tepung tapioka $35 \%$ ), (P3= tepung sagu $75 \%$ : tepung tapioka $25 \%$ ) dan (P4= tepung sagu $85 \%$ : tepung tapioka $15 \%$ ) tidak menunjukkan pengaruh nyata terhadap kualitas sensori dan kimia bakso ikan barakuda (Sphyraena jello) namun memiliki rerata yang beragam pada masing-masing perlakuan. Perlakuan yang menunjukkan kualiatas bakso ikan yang terbaik yaitu perlakuan ( $\mathrm{P} 3=$ tepung sagu $75 \%$ : tepung tapioka $25 \%$ ) dengan nilai kenampakan 4,05 , bau 4,26 , rasa $4,01 \%$ dan tekstur 4,00 .

Kata kunci: Bakso, Ikan barakuda, sagu

\section{PENDAHULUAN}

Provinsi Sulawesi Tenggara tercatat yang mulai berkembang. Selain potensi ekonomi tinggi memproduksi perikanan tangkap sebanyak 151.680 yang diciptakan, potensi kesehatan masyarakat ton pada tahun 2016. Potensi yang dimiliki Sulawesi sangat diperlukan. Para ahli kesehatan dunia Tenggara ini berimbas besar terhadap sektor bisnis menyatakan bahwa ikan dan berbagai jenis seafood 
lainnya sangat baik bagi kesehatan dan kecerdasan manusia. Salah satu sumber daya perikanan yang dihasilkan dari perairan Sulawesi Tenggara adalah ikan Barakuda (Sphyraena jello) dan dikenal dengan nama lokal sebagai ikan alu-alu (Tamarol et al., 2012).

Ikan barakuda (Sphyraena jello) merupakan ikan pelagis yang hidup dekat permukaan, ukuran ikan ini dapat mencapai panjang $100 \mathrm{~cm}$ dan yang umum tertangkap $(60-70 \mathrm{~cm})$. Ikan barakuda merupakan salah satu perairan Indonesia yang pada umumnya sering dikonsumsi oleh masyarakat karena memiliki daging yang gurih, kaya akan kandungan gizi dan memiliki tekstur daging yang baik dan berdaging putih, akan tetapi ikan ini juga cepat mengalami kerusakan dan kemunduran mutu, sehingga perlu adanya proses pengolahan dan pengawetan salah satu bagian penting dari mata rantai industri perikanan.

Pengolahan ikan ini bertujuan untuk menghambat kegiatan zat-zat mikroorganisme, kemunduran mutu dan kerusakan pada daging ikan tersbut (Moeljanto, 1982). Pengolahan dan pengembangan produkproduk perikanan yang bisa dilakukan adalah dengan melalui diversifikasi, sehingga nantinya dapat diikuti dengan cara melakukan peningkatkan produksi dan pada akhirnya dapat mendorong peningkatan dalam pemanfaatan sumber daya perikanan secara optimal. Salah satu bentuk diversifikasi pengolahan ikan atau hasil perikanan yaitu mengelolah menjadi bakso ikan.

Bahan pengisi merupakan bahan yang mempunyai kandungan karbohidrat yang tinggi, sedangkan kandungan proteinnya rendah (Pandisurya 1995 Zainuri, 2010). Proses pembuatan bakso yang ditambahkan bahan pengisi biasanya berupa tepung. Ada beberapa jenis tepung yang sering digunakan dalam pembuatan bakso yaitu, tepung tapioka, tepung terigu, tepung beras, tepung jagung dan tepung sagu. Tepung Sagu adalah bahan pengisi yang berfungsi untuk memperbaiki tekstur, meningkatkan daya mengikat air, memperkecil penyusutan, menambah berat produk dan karena harganya relatif murah maka dapat menekan biaya produksi (Harsanto, 1986). Jumlah tepung yang diberikan dalam pembuatan bakso paling banyak $15 \%$ dari berat daging dan idealnya hanya 10\% (Wibowo, 2000).

\section{Alat dan Bahan}

Peralatan yang digunakan dalam penelitian ini adalah : baskom plastik (komet), sarung tangan (kaka), panci stainless (bima origin), kompor gas (miyako), blender (miyako), cawan petri (Difco), Tabung reaksi (Duran), Pipet volume (Phyrex), Bunsen (Usbeck), Korek api, Incubator (Memmert IN30), Timbangan analitik (Kern), Erlenmeyer (phyrex), Incubator (Memmert).,hot plate, corong, spatula (zebra turner), kapas,ph-meter (hsnna),dan pisau stainless(santoku).

Bahan baku yang digunakan adalah daging ikan barakuda dan tepung sagu (gunung agung) dan tepung tapioka (dua kelinci). Bahan tambahan lain yaitu air es, telur, garam (kapal), bawang, merica, lada. Bahan yang digunakan untuk analisis kimia adalah aquades, $\mathrm{HCL}, \mathrm{H} 2 \mathrm{SO} 4, \mathrm{NaOH}$, kertas saring, heksan dan larutan standar protein.

\section{METODE PENELITIAN}

\section{Metode Pembutan Bakso}

Bakso merupakan produk emulsi daging dengan bahan baku daging yang baik untuk membuat bakso yaitu daging yang segar yang belum mengalami rigor mortis, karena daya ikat air pada ikan segar lebih tinggi bandingkan daging rigor mortis maupun pasca rigor. Bakso dibuat dari daging yang giling halus, ditambah bahan pengisi pati atau tepung sagu dan bumbu-bumbu. Selanjutnyaa donan bakso tersebut dihomogenkan selama kurang lebih 15 menit. Setelah tercampur, homogen adonan. Dicetak menjadi bakso dengan cara dibentuk bulat-bulat menggunakan tangan kemudian direndam dalam air hangat, kemudian direbus dalam airpada temperatur $85-100^{\circ} \mathrm{C}$ sampai bakso mengapung.

\section{Variabel Penelitian}

Parameter yang akandianalisis pada penelitian ini yaitu terdiri dari karakteristik kimia meliputi kadar air, kadar abu, kadar lemak, kadar protein dan karbohidrat.

http://ojs.uho.ac.id/index.php/jfp 
dan analisis sensori yang meliputi warna, aroma, rasa dan tekstur kekenyalan.

\section{Analisis Produk Bakso ikan}

\section{Pengujian sensori (BSN, 2011)}

Pengujian sensori merupakan cara pengujian menggunakan indera manusia sebagai alat utama untuk menilai mutu produk. Pengujian sensori bakso ikan barakuda dengan substitusi tepung sagu dalam penelitian ini menggunakan metode uji skor. Uji skor (scoring test) merupakan metode uji dalam menentukan tingkatan mutu produk berdasarkan skala angka 1 (satu) sebagai nilai terendah dan angka 5 (lima) sebagai nilai tertinggi dengan menggunakan lembar penilaian. Data yang diperoleh dari lembar penilaian ditabulasi dan ditentukan nilai mutunya dengan mencari hasil rerata pada setiap panelis pada tingkat kepercayaan 95\%. Penilaian dilakukan oleh 20 orang panelis yang sudah biasa mengkomsumsi bakso (Meilgaard et al, 1999). meliputi warna, aroma, rasa, dan kekenyalan.

\section{Analisis Proksimat (AOAC 2005)}

\section{a. Kadar Air}

Cawan dikeringkan dalam oven pada suhu $100^{\circ} \mathrm{C}$ kemudian didinginkan dalam desikator dan ditimbang bobotnya (a). Sebanyak $1 \mathrm{~g}$ sampel ditimbang $(b)$ dan dimasukkan ke dalam cawan tersebut. Cawan beserta isinya dimasukkan ke dalam oven bersuhu $100^{\circ} \mathrm{C}$ selama 5 jam, lalu didinginkan dalam desikator dan ditimbang setelah mencapai suhu kamar. Pengulangan dilakukan sampai diperoleh bobot konstan $(c)$. Kadar air dihitung dengan menggunakan rumus :

$$
\begin{gathered}
\text { Kadar Air (\%b/b) x 100\% } \\
a=\text { berat awal aluminium cup } \\
\text { b= berat sampel } \\
c=\text { berat akhir(setelah dioven) }
\end{gathered}
$$

\section{b. Kadar Abu}

Cawan porselen dikeringkan dalam tanur pada suhu $550^{\circ} \mathrm{C}$, kemudian didinginkan dalam desikator dan ditimbang bobotnya (a). Sebanyak $1 \mathrm{~g}$ sampel ditimbang (b) dan dimasukkan ke dalam cawan tersebut, selanjutnya dipijarkan dengan menggunakan pembakar bunsen sampai tidak berasap. Sampel lalu diabukan dengan menggunakan tanur pada suhu 550
${ }^{\circ} \mathrm{C}$ selama 2-4 jam atau sampai diperoleh bobot konstan. Sampel didinginkan dalam desikator dan ditimbang setelah mencapai suhu kamar. Pengulangan dilakukan sampai diperoleh bobot konstan (c). Kadar abu dihitung dengan menggunakan rumus :

$$
\begin{aligned}
& \text { Kadar Abu (\%b/b) } \times 100 \% \\
& \quad \begin{aligned}
a & =\text { berat awal aluminium cup } \\
& b=\text { berat sampel } \\
& =\text { berat akhir (setelah dioven) }
\end{aligned}
\end{aligned}
$$

\section{c. Kadar Lemak dengan Metode Soxhlet}

Labu lemak dikeringkan dalam oven pada suhu $100{ }^{\circ} \mathrm{C}$, kemudian didinginkan dalam desikator dan ditimbang bobotnya (a). Sebanyak $2 \mathrm{~g}$ sampel ditimbang $(b)$, dibungkus dengan kertas saring, dan dimasukkan ke dalam alat ekstraksi (soxhlet) yang telah berisi pelarut $n$-heksana. Proses ekstraksi dilakukan selama 6 jam. Labu lemak yang berisi lemak hasil ekstraksi dikeringkan dalam oven pada suhu 100 ${ }^{\circ} \mathrm{C}$ selama 1 jam kemudian didinginkan dalam desikator dan ditimbang bobotnya (c). Pengeringan dilakukan sampai diperoleh bobot konstan. Kadar lemak dihitung dengan menggunakan rumus :

$$
\begin{aligned}
& \text { Kadar Lemak (\%b/b)x 100\% } \\
& a=\text { berat awal aluminium cup } \\
& b=\text { berat sampel } \\
& c=\text { berat akhir (setelah dioven) }
\end{aligned}
$$

\section{d. Kadar Protein dengan Metode Mikrokjeldahl}

Sebanyak $0.1 \mathrm{~g}$ sampel ditimbang kemudian dimasukkan ke dalam labu kjeldahl $100 \mathrm{~mL}$, ditambahkan $0.25 \mathrm{~g}$ selen dan $3 \mathrm{~mL} \mathrm{H} 2 \mathrm{SO} 4$ pekat. Sampel

dididihkan (didestruksi) selama 1.5 jam sampai larutan menjadi jernih. Larutan kemudian dimasukkan ke dalam alat distilasi, dibilas dengan akuades $2 \mathrm{~mL}$ sebanyak 5 kali, dan ditambahkan $10 \mathrm{~mL}$ larutan $\mathrm{NaOH}-\mathrm{Na2S} 2 \mathrm{O}$ 3. Gas NH3 yang dihasilkan ditangkap oleh $5 \mathrm{~mL} \mathrm{H3BO} 3$ dalam erlenmeyer yang telah ditambahkan 2-4 tetes indikator BCG-MM. Sebanyak $15 \mathrm{~mL}$ kondensat diencerkan menjadi $50 \mathrm{~mL}$ dan dititrasi dengan $\mathrm{HCl} 0.1 \mathrm{~N}$ yang sudah distandardisasi hingga titik akhir titrasi (warna kondensat berubah dari merah muda menjadi hijau). Penetapan blangko 
dilakukan dengan menggunakan metode yang sama seperti penetapan sampel. Kadar protein dihitung dengan menggunakan rumus :

Kadar N (\%) x 100\%

$$
\text { Kadar Protein }(\% \mathrm{~b} / \mathrm{b})=6.25 \times \% \mathrm{~N}
$$

Keterangan :

$\mathrm{b}=$ volume blangko $(\mathrm{ml})$

$\mathrm{s}=$ volume titran $(\mathrm{ml})$

$$
\mathrm{w}=\text { bobot sampel }(\mathrm{g})
$$

\section{Analisis Data}

Untuk mengetahui pengaruh perbedaan terhadap parameter yang akan diamati maka akan dilakukan analisis ragam (ANOVA) dan jika terdapat pengaruh antara perlakuan maka akan dilanjutkan dengan uji Duncan's Multiple Range Test (DMRT) pada tingkat kepercayaan $95 \%(\alpha=0,05)$.

\section{HASIL DAN PEMBAHASAN \\ Hasil}

\section{Uji Organoleptik}

Penilaian organoleptik dimaksudkan untuk mengetahui penilaian panelis terhadap produk yang dihasilkan sesui dengan pendapat (Rampengan et al.,1985). Analisis organoleptik dapat dilihat pada Tabel 1. Tabel 1. Analisis organoleptik dapat dilihat di bawah ini:

\begin{tabular}{lllll}
\hline Perlakuan & Kenampakan + SD & Bau+ SD & Rasa + SD & Tekstur + SD \\
\hline P1 & $4,133+0,1$ & $3,96+0,07$ & $3,916+0,1$ & $3,716+0,07$ \\
P2 & $4,05+0,05$ & $4,083+0,2$ & $4,01+0,05$ & $3,93+0,12$ \\
P3 & $4.15+0,17$ & $4,266+0,2$ & $4,01+0,05$ & $4,00+0,16$ \\
P4 & $3,98+0,02$ & $3,86+0,1$ & $3,96+0,1$ & $3,766+0,02$ \\
\hline
\end{tabular}

\section{Uji Kimia}

Analisis bakso ikan barakuda dengan subtitusi tepung sagu menggunakan analisis proksimat. Analisis proksimat adalah untuk mengetahui komposisi kimia bakso ikan barakuda yang meliputi kadar air, abu, protein, lemak dan karbohidrat. Komposisi kimia bakso ikan barakuda dapat dilihat pada Tabel 2.

Tabel 2. Komposisi kimia bakso ikan barakuda.

\begin{tabular}{lllll}
\hline & \multicolumn{4}{c}{ Sampel } \\
\cline { 2 - 5 } Uji & P1 & P2 & P3 & P4 \\
\hline Kadar Air \% & 65,313 & 64,83 & 63,26 & 63,55 \\
Kadar Abu \% & 1,08 & 1,11 & 1,366 & 1,3 \\
Kadar Lemak \% & 1,01 & 0,97 & 1,05 & 1,01 \\
Kadar Protein \% & 6,67 & 6,86 & 6,65 & 6,16 \\
Karbohidrat \% & 92,146 & 92,413 & 92,09 & 92,58 \\
Keterangan : P1 (Tepung sagu 60 : Tepung Tapioka 60), P2 (Tepung sagu 75 : Tepung Tapioka 45), P3 (Tepung \\
\multicolumn{2}{c}{ sagu 85 : Tepung Tapioka 35), P4 (Tepung sagu 95 : Tepung Tapioka 25). }
\end{tabular}

\section{Pembahasan}

\section{Uji Organoleptik}

\section{a. Kenampakan}

Hasil uji sensori menunjukan bahwa kenampakan memiliki nilai yang berbeda pada setiap perlakuan akan tetapi analisis ragamnya tidak memberikan pengaruh nyata. Berdasarkan Tabel.2 menunjukkan bahwa nilai rerata yang tertinggi pada uji sesuai terlihat pada P2yaitu 4,155\%. Hal ini sesuai dengan proposi penambahan tepung sagu dan daging ikan lebih disukai panulis. Hal ini sejalan dengan pendapat yang dikemukakan oleh Seowarno (2001) bahwa kenampakan merupakan salah satu parameter organoleptik yang penting merupakan faktor yang pertama kali oleh konsumen saat melihat suatu produk dan umumnya konsumen cenderung melihat suatu 
produk yang memiliki kenampakan yang utuh dan warna cemerlang.

Supriato et al. (2015) mengatakan bahwa panelis lebih menyukai kenampakan bakso ikan malong pada perlakuan P2 dengan penggunaan tepung sagu $50 \%$ : tepung tapioka $50 \%$ yaitu dengan nilai 3,20\%. Hal ini karenakan produk yang dihasilkan memiliki bentuk bulat beraturan sedikit berongga dan berwarna putih kream. Hal ini sesuai dengan pernyataan Sunarlin (1992) bahwa penggunaan ikan yang berwarna putih dan tepung tapioka akan mempengaruhi kenampakan dari bakso ikan yang dihasilkan.

\section{b. Bau}

Hasil uji organoleptik terhadap bau pada bakso ikan barakuda memperoleh nilai rerata yang tertinggi pada perlakuan P3 yaitu $4,26 \%$ sedangkan yang terendah pada perlakuan P4 yaitu $3,86 \%$. Hal ini diduga karena bau tepung sagu tidak mempengaruhi bau ikan barakuda. Didukung dengan pernyataan Marliyati dan Anna (2002) menyatakan bahwa Timbulnya bau disebabkan oleh zat yang bersifat vollatil (menguap), sedikit larut dalam air dan lemak. Menurut Pratama et al. ( 2018) volatil dalam ikan berasal dari komposisi kandungan ikan itu sendiri dan dapat berasal dari lingkungan perairan tempat ikan itu tinggal yang akan terakumulasi jaringan lemak dibawa kulit senyawa-senyawa volatil yang berasal dari lemak atau asam lemak pada umumnya yaitu aldehid dan keton yang bersumber pada kativitas berbagai hubungan kimiawi enzimatis dan auto oksidasi lemak.

\section{c. Rasa}

Hasil analisis sidik ragam menunjukkan bakso ikan barakuda dengan subtitusi tepung sagu yang berbeda tidak memberikan pengaruh nyata. Pada Tabel 1 dapat dilihat bahwa nilai rerata yang disukai panelis adalah pada perlakuan P3 yaitu 4,6\%. Hal ini diduga karena rasa ikan pada bakso berasal dari bahan baku yang digunakan. Didukung dengan penyatan Domopili et al. (2011) menyatakan bahwa perlakuan bahan pengisi tidak memberi pengaruh nyata pada rasa ikan pada bakso yang dihasilkan. Rasa yang terbentuk pada ikan barakuda disebabkan karena adanya penambahan garam, bawang putih dalam makanan yang tidak berlebihan sedangkan yang tidak disukai panelis terdapat pada perlakuan P4 yaitu dengan nilai $3,96 \%$. Hal ini diduga karena terlalu banyak campuran tepung sagu sehingga mempengaruhi rasa bakso ikan barakuda. Didukung dengan pernyataan Winarno (1987) menyatakan bahwa semakin banyak bahan pengisi yang ditambahkan akan mempengaruhi rasa pada bakso ikan itu sendiri.

Pakaya et al. (2015) mengatakan bahwa sejumlah senyawa mampu memperkuat aroma dan rasa makanan, misalnya senyawa asam amino terutama glutamat. Adanya interaksi komponen rasa lain dengan komponen utama rasa primer mungkin dapat meningkatkan intensitas rasa atau menurunkan intensitas rasa (taste compensation) (Winarno, 2008). Didukung dengan Galla et al.(2012) selain dari bumbu rasa yang enak juga dikarenakan kandungan asam amino glutamat yang tinggi yang terkandung dalam ikan barakuda 118,54 mg/g protein . berdasarkan hasil penelitian ini ikan barakuda dengan subtitusi tepung sagu dapat diterima dengan baik pada kalangan masyarakat. Menurut Reineccius (2006) asam glutamat yang terdapat dalam makanan cita rasa yang khas atau yang biasa dikenal dengan umami.

\section{d. Tekstur}

Pengujian tingkat kesukaan terhadap tekstur kesukaan bakso ikan barakuda (Sphyraena jello) yang dilakukan oleh panelis diperoleh nilai terbaik pada perlakuan P3 4,00\% dan yang terendah pada perlakuan $\mathrm{P} 13,716 \%$. Berdasarkan hasil analisis sidik ragamnya menunjukkan bahwa bakso ikan barakudadengn penambahan tepung sagu dan tepung tapioka tidak memberikan pengaruh nyata terhadap tekstur bakso. Nilai yang disukai panelis pada perlakuan P3 adalah 4,00\% tekstur yang dihasilkan dari bakso ikan yaitu tekstur yang kenyal. Hal ini diduga karna penambahan pada air adonan saat penggilingan yang rendah, sesuai dengan pernyataan Soeparno (2005).

Babji and Kee (1994) menyatakan bahwa tekstur daging olahan ditentukan oleh kandungan protein dan bahan-bahan pembantu seperti pati, bahan pengikat dan garam sedangkan perlakuan terenda pada P1 
dengan nilai $3,716 \%$ hal ini diduga karena campuran yang kurang pas. Wibowo (2009) menyatakan bahwa tekstur bakso ikan ditentukan oleh banyak sedikitnya campuran bahan pengisi dan bumbu yang digunakan.

\section{Uji Kimia}

\section{a. Kadar Air}

Berdasarkan hasil penelitian rerata kadar air pada bakso ikan barakuda dengan subtitusi tepung sagu memperoleh nilai yang berbeda-beda. Perlakuan terendah pada P3 yaitu dengan nilai $63,26 \%$. Hal ini diduga karena tepung tapioka yang digunakan banyak, sehingga mempengaruhi kadar air bakso ikan barakuda. Didukung dengan pernyataanMaharaja (2008) menyatakan bahwa semakin tinggi tepung yang digunakan dalam pembuatan bakso akan mengurangi kadar air karena tepung sagu dan tepung tapioka memiliki sifat mengikat yang dapat meningkatkan daya ikat air. Perlakuan yang tertinggi pada perlakuan $\mathrm{P} 1$ yaitu dengan nilai $65,31 \%$. Hal ini diduga karena sedikitnya bahan pengisi yang dicampurkan maka akan memmpengaruhi kadar air bakso ikan barakuda. Sesuai dengan pernyataan Winarno (2008) bahwa sedikitnya bahan pengisi yang digunakan maka kadar air akan tinggi. Menurut Domopili et al. (2011) bahwa bakso ikan dengan kadar air yang tinggi (diatas maksimal kadar air SNI) 70 akan mudah bagi bakteri untuk berkembang didalamnya. Kadar yang tinggi mengakibatkan mudahnya bakteri kapang dan khemir untuk berkembang biak sehingga akan terjadi perubahan bahan pangan (Sandjaja 2009).

Menurut Winarno (1993) kadar air pada bakso sangat dipengaruhi senyawa kimia, suhu, konsistensi dan interaksi dengan komponen penyusun makanan seperti protein, lemak, vitamin, asam lemak bebasdan komponen lainnya. Hasil uji analisis kadar air bakso ikan mujair berkisar antara 61,37\% sampai $64,35 \%$. Menurut SNI7266:2014 kadar air yang maksimal yaitu $70 \%$ sehingga kadar air tersebut telah memenuhi standar mutu bakso. Kadar air teringgi adalah perlakuan E $(90 \%$ tepung sagu dan $10 \%$ tepung tapioka) yaitu $61,37 \%$. Berdasarkan penelitian Saprianto et al (2015) bahwa nila rata-rata kadar air bakso ikan malong berkisar antara $28,44 \%-39,15 \%$.

\section{b. Kadar Abu}

Hasil uji rerata kadar abu pada bakso ikan barakuda (Sphyraena jello) yang terendah pada perlakuan P1 1,08\% dan tertinggi P3 1,36\%. Persyaratan kadar abu menurut SNI 01-3818 (2014) kadar abu bakso ikan maksimal 3\% sehingga kadar abu untuk keempat perlakuan pada Tabel 4.3telah memenuhi standar mutu bakso. Perlakuan tertinggi kadar abu pada perlakuan P3 dengan nilai 1,36\%. Hal ini diduga karna kandungan mineral tinggi pada tepung sagu dan tepung tapioka sehingga mempengaruhi kadar abu bakso ikan barakuda. Andarwulan et al. (2011) menyatakan bahwa kandungan mineral tinggi berasal dari tepung sagu dan tepung tapioka. Kadar abu tersusun oleh berbagai jenis mineral dengan komposisi yang beragam tergantung pada jenis dan sumber bahan pangannnya sedangkan terendah pada perlakuan P1 dengan nilai $1,085 \%$. Hal ini diduga karna kandungan meneralnya rendah sehingga mempengaaruhi kadar abu bakso ikan barakuda. Didukung dengan pernyataan (Winarno, 2008) menyatakan bahwa rendahnya kadar abu pada suatu produkmenunjukkan kecilnya jumlah mineral-mineral yang terkandung dalam produk tersebut.

Berdasarkan penelitian Saprianto et al. (2015) bahwa nilai rata-rata kadar abu bakso ikan malong berkisar antara 2,49\%-3,16\% hal ini diduga berasala dari daging ikan itu sendiri dan campurannya. Didukung dengan pernyatan Andarwulan et al. (2011) bahwa kadar abu tersusun oleh berbagai jenis mineral dan komposisi yang beragam tergantung pada jenis dan sumber bahan pangan.

\section{c. Kadar Lemak}

Berdasarkan rerata hasil penelitian bakso ikan barakuda (Sphyraena jello)yang terendah pada perlakuan P1 0,015\% diduga karena tepung sagu sedikit sehingga lemak berkurang didukung dengan Depertemen Kesehatan R.I (1996) yang menyatakan bahwa kandungan lemak pada tepung sagu 0,2 gr/00 gr bahan dengan demikian semakin tinggi tepung sagu yang digunakan maka semakin tinggi lemaknya. Kandungan lemak pada daging dipengaruhi oleh umur, habitat dan jenis makanannya (Winarno, 1993). 
Penelitian Cindy et al. (2012) kadar lemak pada bakso ikan kembung memiliki kisaran antara 4,87\%-2,01\% masih memenuhi standar SNI. 1,0- 2,0 Sejalan dengan pendapat Suzuki (1991) bahwa kadar lemak bakso ikan bermacam-macam tergantung dari jenis ikan,umur ikan, jumlah daging merah, kondisi makanannya serta bahan pengisi dan campurannya.

\section{d. Kadar Protein}

Berdasarkan hasil penelitian pada Tabel 2 kadar protein bakso barakuda (Sphyraen jello) berkisar antara 6,16\% sampai 6,86\% Dari keempat kadar protein bakso ikan barakuda (Sphyraena jello) telah memenuhi standar SNI 01-3818:2014 kadar protein maksimal $7 \%$. Kadar protein tertinggi pada perlakuan P2 yaitu $1,86 \%$ Hal ini diduga karena ikan barakuda memiliki protein yang tinggi sehingga penambahan daging yang banyak akan menyebabkan peningkatan jumlah protein bakso. Oktavia (2011) menyatakan bahwa semakin tinggi protein pada bakso maka akan semakin baik karena fungsinya dalam pembuatan bakso sebagai perekat hancuran daging selama pemasakkan sehingga membentuk struktur yang kompak, protein juga berfungsi sebagai emulsifier. Kandungan protein yang berbeda pada ikan dipengaruhi oleh tepung sagu dan tepung tapioka (Utamaet al., 2010). Kadar protein yang terendah adalah perlakuan P4 (tepung sagu 95\% : tepung tapioka 25\%) dipengaruhi oleh tingginya tepung sagu yang diberikan. Sesuai pernyataan Aulia (2012) bahwa kandungan yang tertinggi padat tepung sagu dan tepung tapioka adalah karbohidrat.

Berdasarkan penelitian Cindy (2012) kadar protein bakso ikan kembung yaitu dengan nilai berkisar sekitar 8,94\%-12,46\%. Hasil penelitian ini menunjukan bahwa semakin sedikit daging ikan kembung yang dimasukkan kedalam adonan maka kadar protein yang terdapat dalam bakso ikan kembung semakin menurun. Menurut Hadiwiyato (1993) bahwa semakin tinggi kadar air dalam suatu bahan pangan yang dihasilkan maka kadar protein semakin rendah karena miogen dan protein larut dalam air. Berdasarkan penelitian Saprianto et al. (2015) bahwa rata-rata kadar protein bakso ikan malong berkisar antara 25,58\%-29,15\%. Hal ini dipengaruhi juga penggunaan bahan pengikat. Semakin tinggi kadar protein bahan pengikat maka berpengaruh terhadap bakso ikan malong (Wirakartakusuma et al., 1986).

\section{e. Karbohidrat}

Berdasarkan hasil penelitian karbohidrat bakso barakuda (Sphyraena jello) berkisar antara 92,09\% sampai $92,58 \%$ hal ini diduga karna kandungan karbohidrat tepung sagu dan tepung tapioka tinggi. Sesuai dengan pernyataan Usmiati (2009) menyatakan bahwa tepung yang digunakan pada pembuatan bakso memiliki kandungan karbohidrat yang tinggi. Pada tepung sagu memiliki kandungan karbohidrat sebesar $69,35 \%$ dan tepung tapioka memiliki kandungan karbohidrat sebesar $88,2 \%$. Menurut Winarno (2004) kandungan gizi dan konsentrasi suatu bahan akan mempengaruhi kandungan gizi pda produk tersebut. Tinggi kandungan karbohidrat bakso ikan barakuda (Sphyraena jello) sangat dipengaruhi kandungan karbohidrat dan konsentrasi proporsi tepung yang digunakan.

Berdasarkan penelitian rata-rata karbohidrat bakso ikan malong dengan menggunakan bahan pengikat yang berbeda memperoleh nilai berkisar antara $27,17 \%$ - 42,03\%. Hal ini disebabkan oleh karena tapioka merupakan pati sebagai salah satu bentuk karbohidrat. Semakin besar penambahan tepung tapioka menyebabkan semakin tinggi karbohidratnya karena tepung tapioka merupakan sumber karbohidrat (Fatriana, 2003). Karbohidrat dihasilkan oleh tumbuhan dan merupakan sumberenergi utama dalam makanan yang mengandung sekitar separuh dalam kalori (Galegher 2008 dalam Handry, 2007). 


\section{KESIMPULAN}

Berdasarkan hasil dan pembahasan maka dapat disimpulkan sebagai berikut:

1. Perlakuan yang berbeda berpengaruh tidak nyata terhadap uji organoleptik pada kenampakan, bau, rasa dan tekstur. Perlakuan terbaik diperoleh pada P3 (tepung sagu 85\% : tepung tapioka $35 \%$ ) dengan nilai kenampakan $4,05 \%$, bau $4,26 \%$, rasa $4,01 \%$ dan tekstur $4,00 \%$.
2. Penambahan tepung yang berbeda menunjukkan nilai kimia yang berbeda dimana perlakukan terbaik di peroleh pada perlakuan P3 ( tepung sagu $75 \%$ : tepung tapioka $25 \%$ ) dengan nilai rerata analisis kimia yaitu kadar air $65,31 \%$, kadar abu 1,3\%, kadar lemak 1,013\%, kadar protein $6,65 \%$, dan karbonhidrat $27,67 \%$.
Babji, A.S. and G.S. Kee. 1994. Change in Colour, pH, WHC, Protein Extraction And Gell Strength During Processing Of Chicken Surimi. Asean Food Journal. 63-68.

Cindy, N.F., Haryati, S dan Larasati. 2012. Karakteristik Fisiokimia Bakso Ikan Kembung (Rastrelliger kanagurta) dengan Substitusi Tepung Sagu.

Domopoli., R., Assa., J.R., Kandou., J. 2011. Karakteristik Organoleptik dan Kimia Bakso Ikan Mujair (Oreochromis mossambicus) Yang Disubtitusikan dengan Tepung Sagu (Meroxylon sagu ) Sebagai Bahan Pengisi. (Skripsi). Jurusan Teknologi Pertanian . Fakultas Pertanian. Universitas Sam Ratulangi.

Gala, N.R.K Balaswomy, A. Satyanararyana, and P.P Galla. 2012. Physico Cemical Amino Acid Composition Functional And Antioxiddant PropertiesbOf Roe Protein Concentrates Obtainl From Channa Striatus And Lates Calcalifer Food Chemistry.

Harsanto, P.B. 1986. Budidaya dan Pengolahan Sagu. Kanisius. Yogyakarta

Marliyati, dan Anna, S., 2002. Pengolahan Pangan Tingkat Rumah Tangga. Departemen Pendidikan dan Kebudayaan Direktorat Jendral Pendidikan Tinggi Pusat Antar Universitas Pangan dan Gizi Institute Pertanian Bogor. Bogor Journal Off Nutrition College. 1 (1) : 389.

Oktavia, R. 2011 Http:/rinioktavia19942.wordpress.com/2011/0 7/01/fungsi protein/. Diakses pada tanggal (27 oktober 2016).

Prakaya, R., Mandey, C. L., Lumoindong, F. 2015.
Pengaruh penambahan Tepung Tapiokan Terhadap Kandungan Gizi dan Organoleptik Ikan Gabus (Channa striata). Teknologi Hasil Peranian. Universitas Dumoga Kotamobagu Program Studi IImu Pangan Pasca Sarjan. Universitas Sam Ratulangi. Manado. Ilmu Dan Teknologi Pangan. Vol. 3 No. 2.

Reineccius, G. 2006. Flovour Chemistry And Teknologi. Second Edition Boca aton : CRC Press, LLC.

Sandjaja. 2009. Kamus Gizi Pelengkap Kesehetan keluarga. Jakarta : PT Kompas Medida Nusantara.

Soeparno. 2005. Ilmu dan Teknologi. Yogyakarta: Gajah Mada. University Press Soxtec TM2045 Extraction Unit. User 1000 1992/ Rev. 2003. 2.Foss Analytical AB Sweden.

Suzuki, 1991.Karateristik Fisik kimia dan Organeleptik Bakso Ikan Kembung (Rasteresttiger Kanagurta)Dengan Subtitusi Wortel (DeucusCorota). Pertanian Universitas Semarang.

Wibowo, S. 2009. Membuat Bakso Sehat dan Enak. Swadaya : Jakarta

Winarno, 1993. Pangan Gizi Teknologi dan Konsumen. Jakarta: PT media Pustaka Utama. 